ALEX CESESKI, Department of Plant Sciences, University of California, Davis; KASSIM AL-KHATIB, Professor, Department of Plant Sciences, University of California, Davis; and JEFFREY A. DAHLBERG, University of California Kearney Agricultural Research and Extension Center

\section{Biology and Management of Johnsongrass (Sorghum halepense)}

\section{INTRODUCTION}

\section{ohnsongrass (Sorghum halepense) is a summer perennial grass native to the Mediterranean region. It} was introduced to the Southern United States in the early 1800 s as a perennial forage crop and is still in use for cattle grazing in many states. After introduction, it escaped cultivation and is now present or naturalized in nearly every state in the continental United States. It is recognized as invasive or as a noxious weed throughout the south, southwest, and west and is one of the ten most troublesome weeds in the world. In California johnsongrass is classified as a "C" list noxious weed (Fig. 1).

Johnsongrass reaches 6 to 8 feet in height, with wide open, purplebrown panicles 4 to 20 inches long (Fig. 2). Stems and leaves are bright to deep green; leaves have a prominent white midvein and may reach 1 inch or more in width and 24 or more inches in length. Johnsongrass can reproduce via seed through self- or cross-fertilization and will reproduce vegetatively via a robust rhizome network.

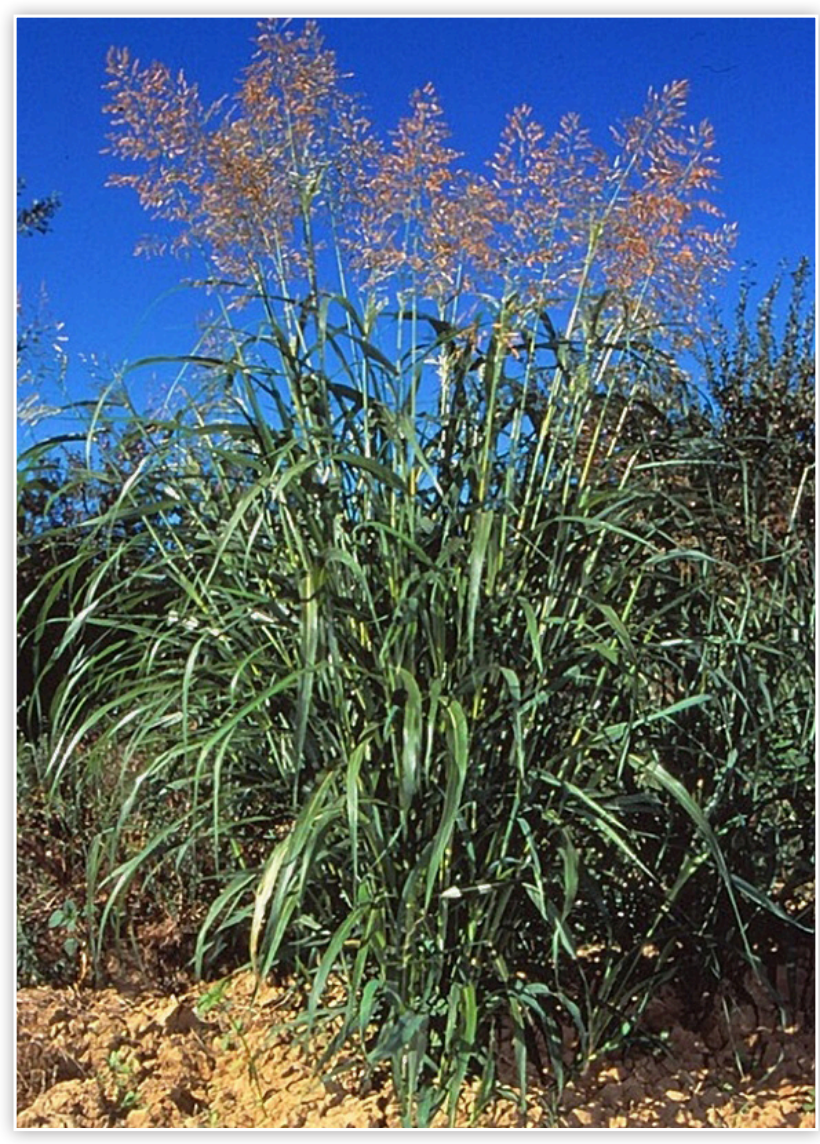

Figure 1. Mature johnsongrass stand. Photo: J. M. DiTomaso. 

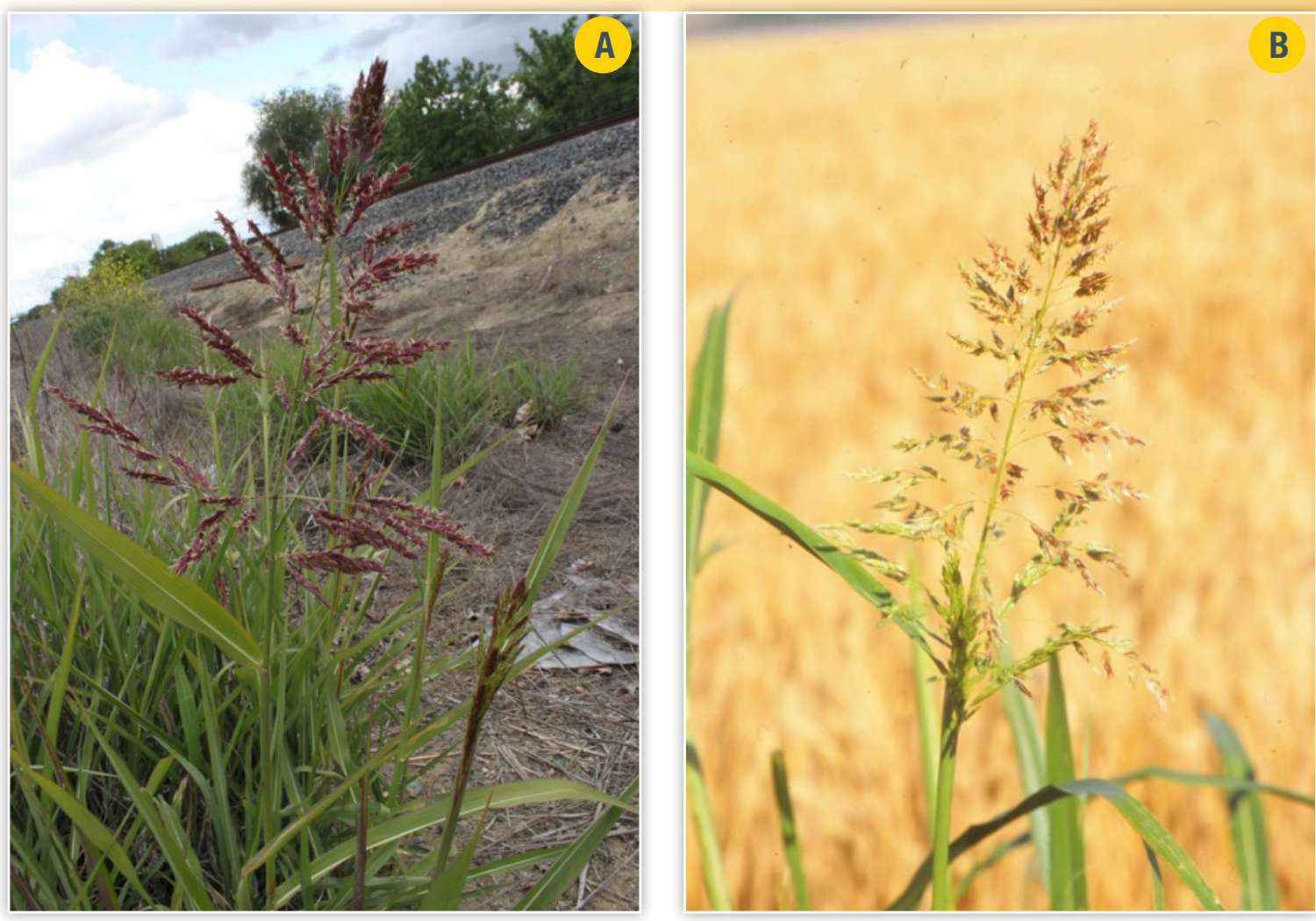

Johnsongrass establishes well in disturbed areas, rangelands, pastures, abandoned fields, and canals, as well as in virtually any cropping system. It thrives in moist environments, but due to its extensive rhizome system it can persist in drier topsoils if they are above high water tables. Johnsongrass may not be a significant threat to recovered areas with sufficient established vegetation, so avoiding disturbance in these areas is critical to preventing new or repeat infestations. Infestations usually begin in the margins of affected areas, but livestock and machinery may inadvertently spread seed to the interiors of fields, orchards, pastures, and other areas. Johnsongrass is an alternate host to Maize Dwarf Mosaic Virus (MDMV), which affects corn (Zea mays), oats (Avena sativa), millets such as pearl millet (Pennisetum glaucum) and foxtail millet (Setaria italica), and sorghum (Sorghum bicolor). The presence of the virus in crops is often attributable to a nearby johnsongrass infestation. It also readily hybridizes with grain, forage, or sudangrass sorghums, which can reduce harvest quality due to contaminated seed.
Figure 2. Johnsongrass panicles. A: Early-season panicle. Note emerging panicle in background. B: Mature panicle. Photos: A. Ceseski (A), J. M. DiTomaso (B)

Since johnsongrass builds a substantial rhizome system in its first year, it can be very difficult to control once it is well established. Rhizome sprouts typically emerge early in the season and quickly reach full height, and they can easily outgrow and overtop desired plants. In addition, the extensive rhizome network can allow a single plant to be very competitive for water and nutrients over a substantial area.

Significant crop yield reductions can be expected with acute johnsongrass infestation. For example, cotton can see a $20 \%$ yield reduction with as few as two tillers per square foot within rows (Keely and Thullen 1981). Corn without adequate control of johnsongrass can see yields reduced by up to 2 to 3 tons (70 to 100 bushels) per acre (Nagabhushana et al. 1995). Additionally, disturbed portions of noncrop areas can quickly become dominated by thick stands of johnsongrass if management is not practiced.

\section{Life Cycle and Physical Characteristics}

Johnsongrass can grow from seed or from overwintering rhizomes. Seed can germinate within a year and can remain viable for up to 6 years in the soil. Seedlings may form new rhizomes as early as the 5- to 6-leaf stage, about a month after emergence; buds of the new rhizomes may sprout the following year. Rhizome sprouting typically occurs in the early spring when daytime temperatures average above $60^{\circ} \mathrm{F}$, but seed will germinate later, when daytime temperatures are about $70^{\circ}$ to $75^{\circ} \mathrm{F}$. Date ranges for rhizome and seedling emergence vary by region, but early to late March for warmer areas and late March to mid April for cooler areas are good approximations. Sprouts from new rhizomes grow more rapidly than from seed, but both grow quickly, and their development is essentially identical 

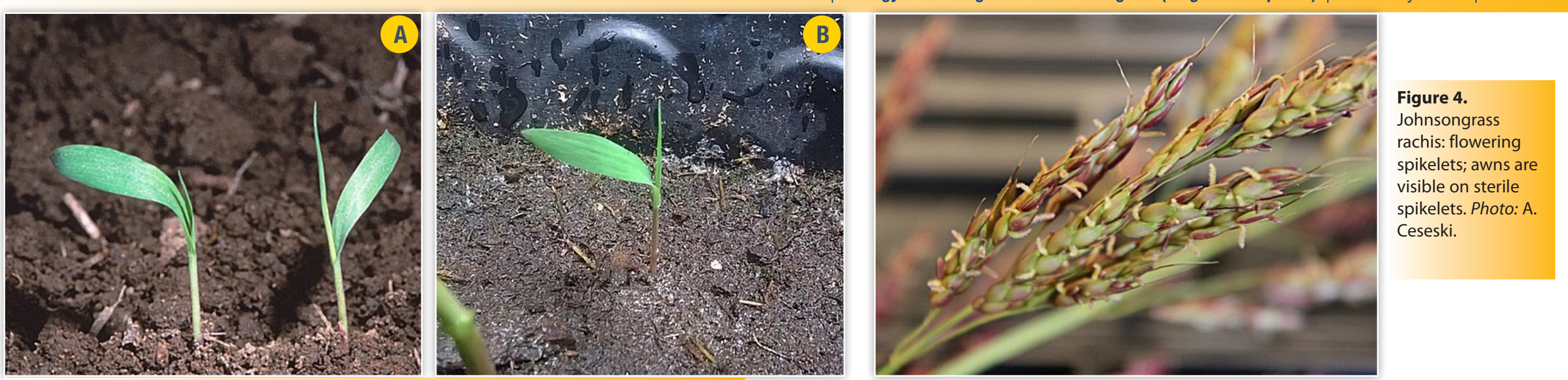

Figure 3. A: Johnsongrass seedlings. B: Johnsongrass rhizome sprout. Note that both the seedlings and the sprout are nearly indistinguishable. Photos: J. M. DiTomaso (A), A. Ceseski (B).

(Fig. 3). Tillers usually appear at the 6-leaf stage, about a month after emergence. Flowering usually occurs 2 months from emergence and in California typically lasts from May to October, with each panicle producing up to 400 seed (Fig. 4). The rhizome network later expands during seed ripening; individual plants can produce 200 to 300 feet of new rhizome growth per year (Fig. 5). Aboveground structures and older rhizomes die off over winter, but new rhizome growth persists and forms new sprouts the following spring. Because it can propagate via self-crossing and rhizomes, a single plant, if left undisturbed, can cause a significant infestation of up to 180 square feet in 2 years (Fig. 6).

Johnsongrass seedlings can resemble young corn seedlings, but because their seed remain attached, johnsongrass is easily discernable if plucked. The first leaf is usually parallel to the ground; early leaves have a smooth surface with no discernable midrib and smooth edges. A white midvein may begin to show at the leaf base of seedlings. Seedling collars are usually pale green to whitish, and sheaths may begin to take on a red-purple tinge as the plant matures.

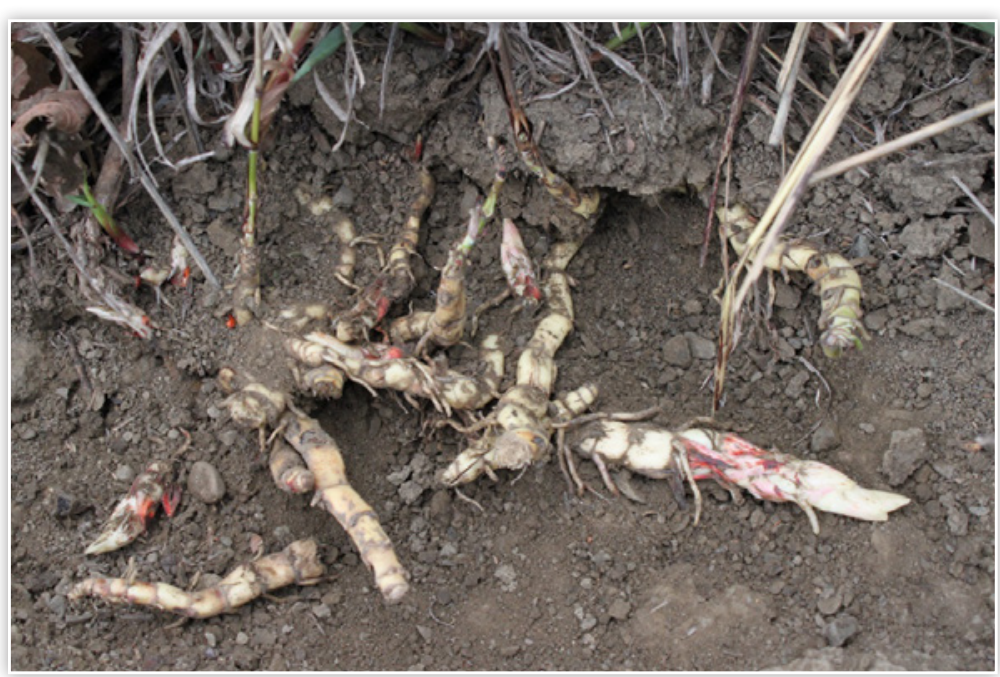

Figure 5. Cluster of johnsongrass rhizomes. Note the scaly texture and cream to red color. Photo: A. Ceseski.

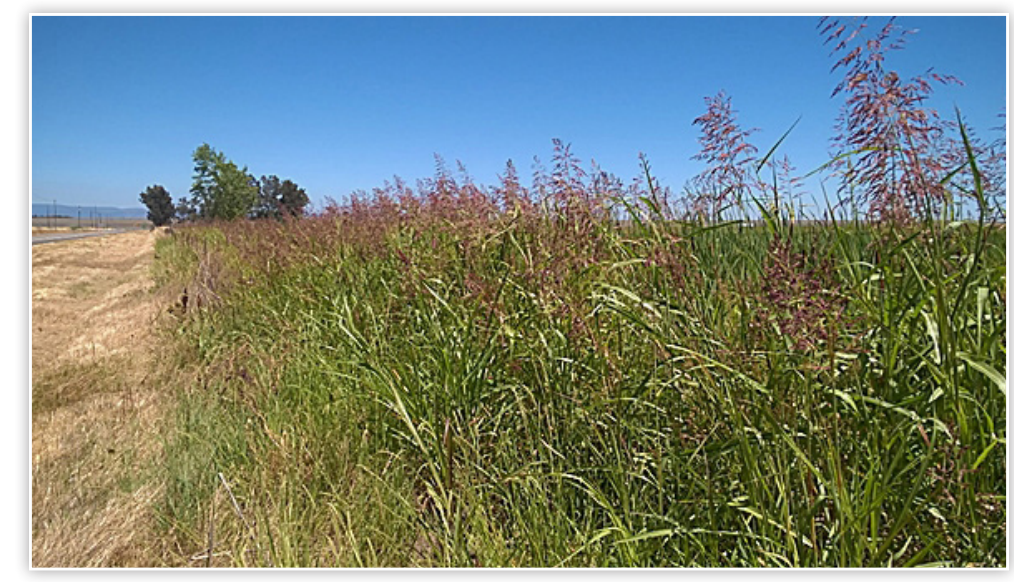

Figure 6. A large roadside johnsongrass infestation. Photo: A. Ceseski. 


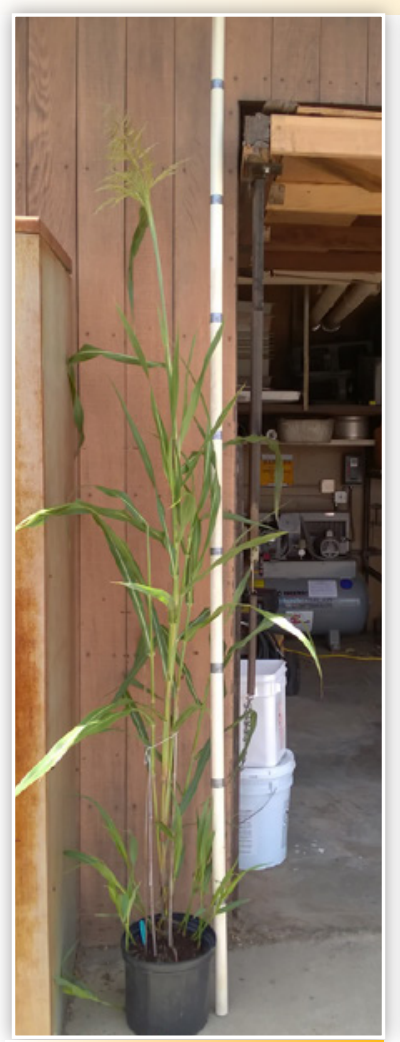

Figure 7. Johnsongrass can reach 8 feet in height. Photo: A. Ceseski.

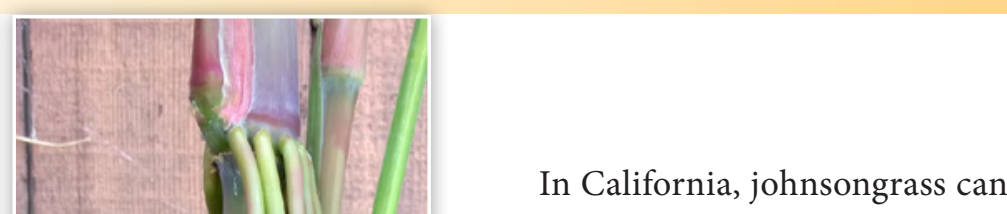
be as much as 8 feet tall at maturity (Fig. 7). Stems grow from the crown, are erect and unjointed at the nodes, and may have a red-purple base or tinted internode. Nodes may have some fine hairs, but internodes are usually smooth. Prop roots may form near the base of stems (Fig. 8). The leaves are rolled in the bud, generally emerge flat, and have a prominent midrib, especially at the base (Fig. 9). Mature leaves are hairless to nearly hairless and may have slightly rough edges, with a prominent fringed ligule up to $0.2 \mathrm{inch}$ long or more (Fig. 10). Sparse hairs may be present on the leaf or sheath near the collar. Inflorescences form as large, open panicles that are pyramidal or conical in shape. Spikelets can range from pale green or gray to golden to purple-brown. They may remain on the
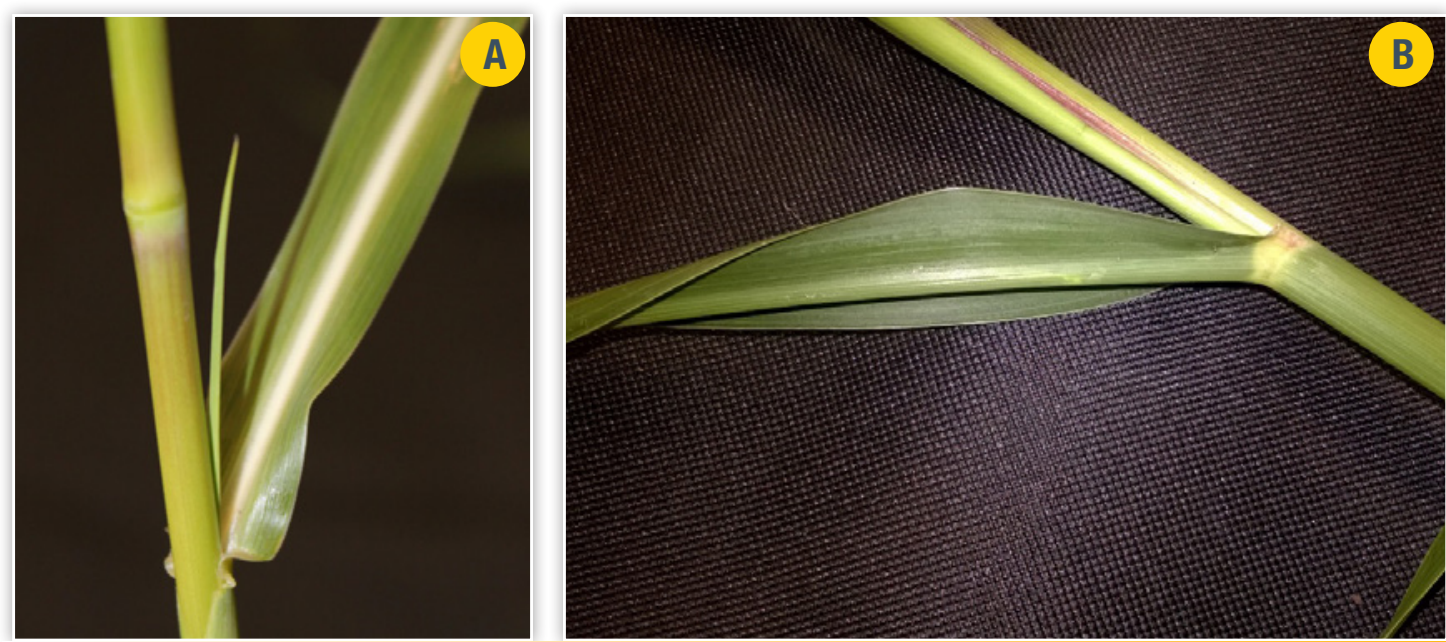

Figure 9. A: White midvein and an emerging leaf rolled in the bud. Note the purple tinge beginning to show on the internode. B: Prominent midrib on leaf underside. Photos: A. Ceseski.

panicle or shatter into pairs or trios that consist of a lower fertile spikelet and one or two sterile upper spikelets. Fertile spikelets are 0.15 to 0.25 inch long, and the smaller sterile spikelets may have bent and twisted awns up to 0.6 inch long (see Fig. 4)). Rhizomes are branching, scaly, and fibrous, 0.5 inch or more in diameter, and reach up to 6 feet long. Rhizomes are usually cream or tan, may have reddish brown streaks, and form a dense sod by the end of the season (Fig. 11).
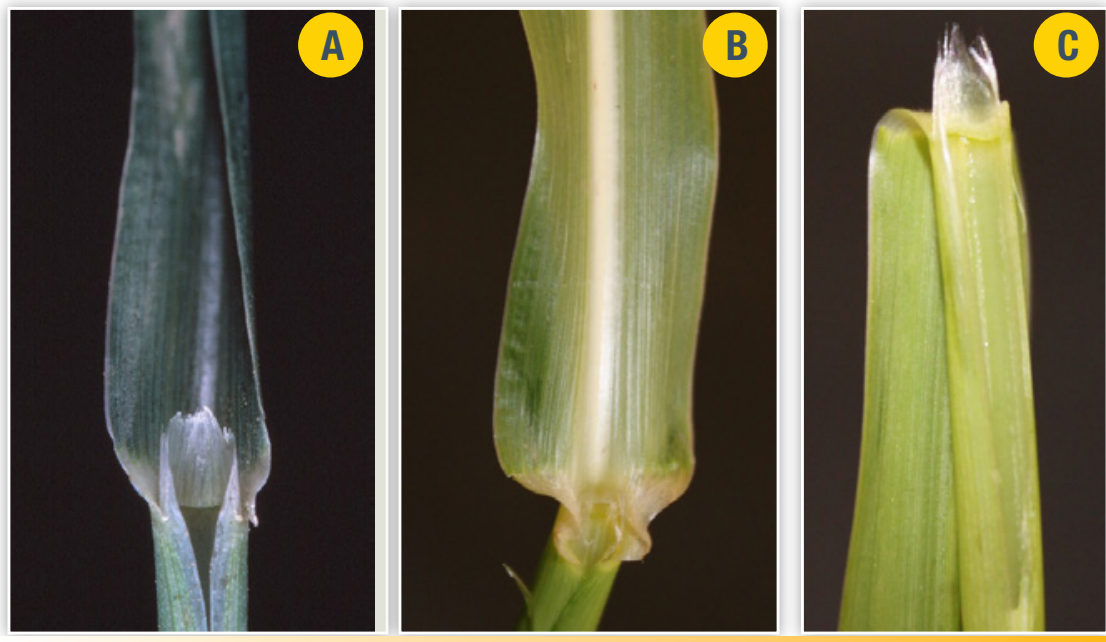

Figure 10. Johnsongrass ligules are variable. A: A prominent membranous ligule. B: An almost totally hidden ligule, which is composed entirely of fringe. C: A partially hidden fringed membrane ligule. Photos: J. M. DiTomaso (A); A. Ceseski (B and C).

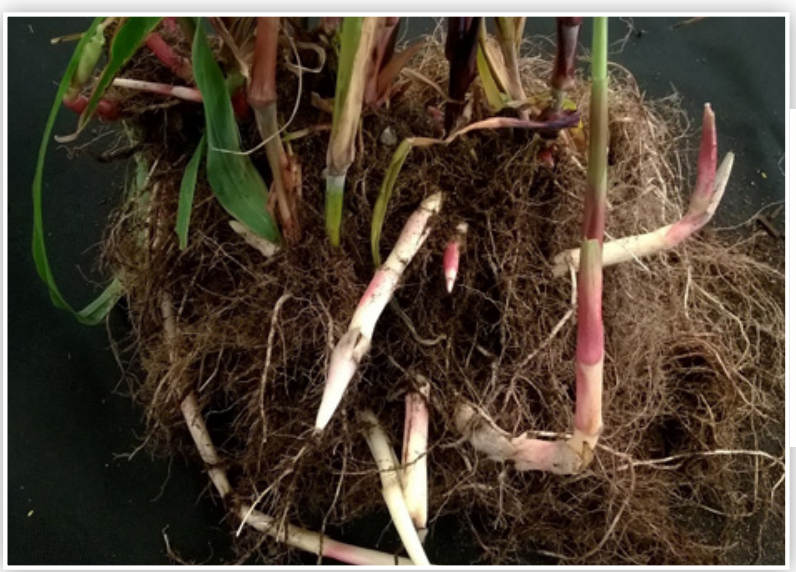

Figure 11. A sod of johnsongrass rhizomes. Photo: A. Ceseski. 


\section{Management}

Effective management of established infestations can be extremely difficult. Johnsongrass readily colonizes disturbed areas, so field margins, canals, ditches, rights-of-way, and roadsides must be monitored closely if an infestation is suspected. Care must be taken in pasture sown with johnsongrass as forage to prevent its escape. Livestock that may have eaten johnsongrass seed should not be taken to a johnsongrass-free pasture for at least a week, to prevent the spread of seed through feces. Cleaning of equipment, especially shared or rented equipment, prior to relocation is an essential preventative measure against its spread into new areas.

A sound, integrated strategy must be employed to achieve suitable management, whether the infestation is in crop land or nonagricultural sites. In general, a management strategy must be a multiyear effort if the infestation is well established. It should focus on

- prevention or control of seed import

- depletion of the existing seedbank

- killing seedlings and sprouts early, before rhizomes begin to form or seed are produced (before the 5 to 6 leaf stage, which is about 1 month after emergence)

- depleting energy stores of existing rhizomes

Although a variety of methods to manage johnsongrass are available, the most effective strategy is to integrate mechanical, biological, and chemical means.

\section{Mechanical}

\section{Manual}

Hand-weeding is effective only when the plants are young and when the soil is softened or loose enough to remove all roots and rhizomes without fragmenting them. Caution must be used when pulling or hoeing, as any rhizome fragments left in the soil can sprout new growth. The entire plant should be removed if possible. This is more easily done with smaller seedlings, as their rhizome system is rudimentary. However, sprouts may be attached to a large sod of rhizomes and roots, in which case removal of the entire plant may be impossible by hand. For these reasons, weed pullers are generally discouraged.

\section{Mowing}

Johnsongrass is known to be unable to tolerate repeated mowing. Mowing depletes the energy stores in the rhizomes and can reduce new rhizome growth. Mowing should begin when the plants are about 8 to 12 inches tall, before panicle initiation-boot stage, and continue at intervals of 2 to 4 weeks. Mowing can kill seedlings but may not kill all rhizomes, so when used alone it will only suppress established infestations, not control them.

\section{Tillage}

Tillage can aid carbohydrate depletion, but it must be used judiciously and only as a part of an integrated management program. Tillage is most effective when the soil is dry, as dried rhizomes are less likely to sprout, and any sprouts will be less vigorous. Summer fallowing can help maximize the effects of tillage, but only where the water table is not too shallow. Johnsongrass rhizomes have buds along their length, but only buds at the tips are active. When fragmented by discing, plowing, or other means, the dormant buds can awaken and send up shoots the current year or the next, depending on the timing of the field operations. A single tillage in spring will most likely result in a more-pronounced infestation. Therefore, early season tillage must be followed by repeated tillage, cultivation, mowing, or herbicide applications every 3 to 4 weeks to control new sprouts. Discing followed by mowing or discing followed by spraying can be effective in reducing an infestation year after year. Use caution when employing deep tillage or plowing, as fragmented rhizomes can send up sprouts from as deep as 12 inches below the soil surface. Postharvest tillage and fallowing can also be an effective management method, as desiccation can weaken or kill rhizomes. If the harvest is early, desiccation above $85^{\circ} \mathrm{F}$ for 5 or more days can kill rhizome buds. Late-season tillage can expose some rhizome fragments to killing frost and desiccation, and surviving fragments should produce less-vigorous sprouts the following spring.

\section{Flaming and Solarization}

Propane flaming has been used effectively, but it is usually more expensive than spraying or mowing. It is effective if used biweekly or monthly to manage seedlings and weaken rhizomes. Solarization 
immediately following harvest may be attempted, as rhizomes do not tolerate high temperatures. Three to five days at above $130^{\circ} \mathrm{F}$ should kill most rhizomes, but high temperatures will occur in about the first 2 inches of soil depth.

\section{Biological}

Grazing can be used in lieu of mowing to manage seedlings and sprouts, but it will not harm rhizomes. Geese can also be used as a management aid in orchards and broadleaf crops, as they preferentially eat grass seedlings. Food-safety guidelines and best practices must be followed when using livestock as a pest control agent in crops. Grazing and weeder geese can also be used in noncrop areas. In all livestock-management schemes, ingested seed may pass through the animals undamaged, so care should be used when moving animals after grazing. Additionally, many herbicides restrict or forbid grazing of treated areas of certain crops; refer to the herbicide labels for specific details.

Caution must be observed when johnsongrass is used as forage or when using grazing as a management method. When stressed by drought, frost, or injury, johnsongrass leaves can build up toxic amounts of hydrocyanic acid (cyanide), which can be toxic or lethal to livestock. For this reason, grazing is not recommended until plants are 15 to 18 inches tall. Additionally, johnsongrass can accumulate toxic levels of nitrates when stressed or in soils with high nitrate concentration. Dried johnsongrass cuttings that contain cyanide or high nitrate levels are still unsafe, but well-cured hay should be safe for livestock.

\section{Chemical}

Many herbicides are available for controlling johnsongrass, but not every herbicide is equally effective against it, and many can damage desired vegetation. Selection of the correct herbicide for an infested area is critically important. Herbicides that select for broadleaves, e.g., 2,4-D and dicamba, have little to no effect on johnsongrass, and some broad-spectrum and grass-selective herbicides may not be as effective on perennials like johnsongrass as they would be on annual grasses, even at maximum rates.
Since the rhizome system of johnsongrass is so large and spreads so rapidly, killing the below-ground tissues or depleting carbohydrate stores is usually the primary goal with herbicide use. Many preemergent (PRE) and preplant-incorporated (PPI) herbicides can control seedlings and prevent reseeding, but they are unlikely to be effective against established plants and rhizomes. As such, the use of PRE herbicides may not be a good strategy in early-stage growth unless the target is to control only seedlings and sprouts. However, PRE herbicides such as EPTC, benefin, napropamide, trifluralin, and norflurazon can provide limited suppression of established plants. Contact herbicides, all postemergent (POST) applied to growing plants can prevent the development of seed and new rhizome growth but do not kill existing rhizomes, so new sprouts can be expected in the same season. In order to kill rhizomes, systemic POST herbicides such as glyphosate, fluazifop, clethodim, and sethoxydim are recommended. When applied early in the season these herbicides can prevent flowering but will only have a limited effect on rhizomes. Therefore, systemic POST herbicides are most effective against rhizomes when applied after flowering, when rhizomes are growing vigorously. Grass-selective herbicides like fluazifop, sethoxydim, and clethodim provide their most effective control when plants are 8 to 18 inches tall, though repeat applications may be needed. Glyphosate is most effective on actively growing plants that are 12 to 24 inches tall. Always consult the herbicide's label for a list of common weeds controlled, as well as the legal limits on application rates and registered crops.

Managing johnsongrass in the summer may be most effective in fallow fields, especially if left fallow for multiple summers. During a fallow season, multiple tillage and herbicide operations can maximize carbohydrate depletion and rhizome death. For fields with annual crops, a strategy of early preplant tillage to fragment rhizomes followed by light irrigation to encourage sprouting, mowing to deplete rhizomes, and application of a POST herbicide on actively growing plants can significantly reduce the competitiveness of johnsongrass. In this strategy, sprouts appearing after planting should also be expected and can be handled via cultivation and 
spot or band herbicide applications. In broadleaf crops, grass herbicides like fluazifop, clethodim, and sethoxydim are good options for controlling johnsongrass without harming crop plants. Perennial field crops will likely need between-row cultivation and spot application of herbicides to minimize damage to crops. In orchards, johnsongrass should be less invasive when canopies are closed and will likely be found only along field margins, so effective management of new infestations may be accomplished with mowing and a spot application of a POST herbicide. Established infestations in smaller tree orchards, such as prunes, may require cultivation between rows to about an 8-inch depth to fragment rhizomes and later a spot application of herbicide to kill new sprouts. In noncrop areas, herbicides used in conjunction with mowing can be effective in managing or even eradicating johnsongrass, but care must be taken when selecting herbicides, as the desired vegetation may consist of species with different susceptibilities to the chemicals.

\section{Herbicides}

Many herbicides are effective in controlling johnsongrass, but overreliance on one type of herbicide can impose selection pressure on johnsongrass populations to develop herbicide resistance. Herbicide-resistant populations of johnsongrass have been reported in several states, however to date there has been no reported herbicide resistance in California populations of johnsongrass. In general, the most common types of herbicide resistance have been to

- acetolactate synthase (ALS) inhibitors (also known as acetohydroxy acid synthase, or AHAS) such as nicosulfuron, imazethapyr, and rimsulfuron

- acetyl-CoA carboxylase (ACCase) inhibitors such as fluazifop, sethoxydim, and clethodim

- the microtubule inhibitor pendimethalin

- glyphosate
A more effective and sustainable johnsongrass management strategy should incorporate a variety of herbicide modes of action in order to decrease the possibility of herbicide resistance. Some johnsongrass populations may simply be tolerant to an herbicide, requiring a dosage far higher than usual to kill, while others may be totally resistant, in which case the plant will survive the treatment even if the rate of herbicide is significantly increased .

Table 1 summarizes pesticide recommendations from product labels at the time of publication. Always refer to the current product label for complete instructions and restrictions.

In addition to the federally required label, many herbicides used for johnsongrass management may have a supplemental Special Local Need (SLN) label for specific instructions or limitations for handling and use. In addition, some California counties may restrict or forbid the use of certain herbicides. Application rates may must be adjusted based on soil textures and $\mathrm{pH}$, and many herbicides restrict or forbid use on soils that are frozen, compacted, or that have high levels of organic matter. In addition, many herbicides have requirements or restrictions for irrigation before or after application, or when applied to plants under stressed conditions. Management of johnsongrass may be diminished or crop injury may occur if herbicides are applied under nonspecified conditions. Furthermore, many herbicides have postapplication restrictions on reentry, minimum preharvest intervals, crop rotation, replanting, or grazing. Foliar herbicides usually require adjuvants such as nonionic surfactants, crop oil concentrates, or methylated seed oils in the final mixture. 
Table 1. Herbicide general information. Read and follow approved uses, timing, and rates on the pesticide label.

\begin{tabular}{|c|c|c|c|c|}
\hline Herbicide & Approved use & Timing & Rate & Comments \\
\hline clethodim & Refer to label for approved uses. & $\begin{array}{l}\text { POST: Apply when johnsongrass is } 12-24 \text { inches } \\
\text { tall. If rain is expected, apply more than } 1 \text { hour } \\
\text { before rain and less than } 7 \text { days after rainfall or } \\
\text { irrigation. }\end{array}$ & $\begin{array}{l}1.5-4 \text { oz a.i./acre in a } 5 \text { - to } 40 \text {-gal volume; } \\
8 \text { oz a.i. max/acre/season. }\end{array}$ & $\begin{array}{l}\text { Grass-selective herbicide. Tillage or cultivation to } \\
\text { fragment rhizomes prior to spraying is recommended; } 2 \\
\text { or more applications will likely be needed for best control; } \\
\text { respray after } 14 \text { days. }\end{array}$ \\
\hline dimethenamid & $\begin{array}{l}\text { Corn (except sweet), garlic, onions, potatoes, } \\
\text { sugarbeets. }\end{array}$ & $\begin{array}{l}\text { PRE-incorporated: Apply up to } 14 \text { days before } \\
\text { planting and incorporate to } 2 \text { inches. PRE- } \\
\text { surface: Apply from } 45 \text { days before planting to } \\
\text { preemergence; requires immediate rainfall or } \\
\text { irrigation. }\end{array}$ & $\begin{array}{l}9 \mathrm{oz}-1 \mathrm{lb} \text { a.i./acre in a minimum } 5 \text {-gal } \\
\text { volume; } 1 \mathrm{lb} \text { max/season. }\end{array}$ & $\begin{array}{l}\text { Effective only on seedlings. Do not apply to coarse soils } \\
\text { with less than } 3 \% \text { organic matter (OM). }\end{array}$ \\
\hline diquat & $\begin{array}{l}\text { Artichokes, asparagus, blueberries, most tree } \\
\text { and vine crops, potatoes. }\end{array}$ & $\begin{array}{l}\text { POST-contact: Can overhead irrigate } 30 \text { minutes } \\
\text { after application. }\end{array}$ & $\begin{array}{l}0.5 \mathrm{lb} \text { a.i./acre in a minimum 15-gal } \\
\text { volume. }\end{array}$ & $\begin{array}{l}\text { Use only on nonbearing crops, except potatoes. Most } \\
\text { effective on johnsongrass seedlings; may kill aboveground } \\
\text { sprouts and weaken rhizomes but regrowth should be } \\
\text { expected. }\end{array}$ \\
\hline diuron & $\begin{array}{l}\text { Alfalfa, apples, artichokes, asparagus, } \\
\text { caneberries, citrus, corn, cotton, grapes, } \\
\text { noncrop areas, olives, peaches, pears, pecans, } \\
\text { walnuts. }\end{array}$ & $\begin{array}{l}\text { PRE-surface: Irrigate within } 2 \text { weeks of } \\
\text { application. }\end{array}$ & $\begin{array}{l}\text { Crops: } 1.6-4.8 \mathrm{lb} \text { a.i./acre in a } 25 \text {-gal } \\
\text { volume, } 12 \mathrm{lb} \text { a.i. max/season/acre; } \\
\text { noncrop areas: } 4-6.4 \mathrm{lb} \text { a.i./acre in a } 5 \text { - to } \\
25 \text {-gal volume, } 12 \mathrm{lb} \text { a.i. max/season/acre. }\end{array}$ & $\begin{array}{l}\text { PERMIT REQUIRED for some crops. Do not use in } \\
\text { residential areas. }\end{array}$ \\
\hline EPTC & $\begin{array}{l}\text { Alfalfa, almonds, beans, nonbearing citrus, cole } \\
\text { crops, cotton, potatoes, safflower, sugarbeets, } \\
\text { sunflowers, tomatoes, walnuts. }\end{array}$ & PRE-incorporated: Incorporate up to $2-3$ inches. & $\begin{array}{l}2-8 \mathrm{lb} \text { a.i./acre in a minimum } 10-\mathrm{gal} \\
\text { volume; refer to label for maximum rate } \\
\text { for different crops. }\end{array}$ & $\begin{array}{l}\text { Refer to label for crop-specific instructions. Cultivation } \\
\text { prior to application is necessary for maximum } \\
\text { effectiveness. Does not control emerged seedlings at time } \\
\text { of application. }\end{array}$ \\
\hline ethalfluralin & Beans, sunflowers. & $\begin{array}{l}\text { PRE-incorporated: Incorporate to } 2-3 \text { inches. } \\
\text { PRE-surface: Apply immediately after tillage and } \\
\text { immediately before irrigation. }\end{array}$ & $\begin{array}{l}1.1-1.7 \mathrm{lb} \text { a.i./acre in a minimum } 5 \text {-gal } \\
\text { volume; refer to label for maximum rate } \\
\text { by crop. }\end{array}$ & Effective only on germinating seedlings. \\
\hline fluazifop & $\begin{array}{l}\text { Apricots, asparagus, beans, carrots, cherries, } \\
\text { citrus, cotton, garlic, grapes, nectarines, onions, } \\
\text { peaches, pecans, plums, prunes, sugarbeets, } \\
\text { walnuts and nonbearing almonds, apples, } \\
\text { avocado, dates, figs, olives, peaches, pears, } \\
\text { pistachios, pomegranate. }\end{array}$ & $\begin{array}{l}\text { POST-contact: Seedling control at } 2-4 \text { inches } \\
\text { tall, rhizome control at } 12-18 \text { inches tall. }\end{array}$ & $\begin{array}{l}2-6 \text { oz a.i./acre in a minimum } 5 \text {-gal } \\
\text { volume; refer to label for maximum rate } \\
\text { by crop. }\end{array}$ & $\begin{array}{l}\text { Controls only grasses. Do not overhead irrigate for } 1 \text { hour } \\
\text { after application; best results if applied within } 7 \text { days of } \\
\text { irrigation. Most effective on actively growing plant; apply } \\
\text { before johnsongrass reaches boot stage. }\end{array}$ \\
\hline flumioxazin & $\begin{array}{l}\text { Alfalfa, almonds, artichokes, asparagus, } \\
\text { caneberries, celery, corn, cotton, garlic, most } \\
\text { tree and vine crops, onion, safflower, small } \\
\text { grains, strawberries, sunflowers. }\end{array}$ & $\begin{array}{l}\text { PRE-surface: Best results obtained if applied } \\
\text { when seedlings are } 4-8 \text { inches tall or sprouts are } \\
6-18 \text { inches tall. }\end{array}$ & $\begin{array}{l}\text { 1.5-6 oz a.i./acre in a minimum } 10 \text {-gal } \\
\text { volume; } 1.5-6 \text { oz a.i. max/season/acre. }\end{array}$ & $\begin{array}{l}\text { Incorporation will diminish effectiveness. Do not irrigate } \\
\text { within } 1 \text { hour of application. Refer to label for restrictions } \\
\text { on bearing and nonbearing trees; do not apply within } 300 \\
\text { yards of nondormant pears. }\end{array}$ \\
\hline glufosinate & $\begin{array}{l}\text { Caneberries, corn (LibertyLink), cotton, most } \\
\text { tree and vine crops, noncrop areas. }\end{array}$ & $\begin{array}{l}\text { POST-contact (burndown use): Use on young, } \\
\text { actively growing plants. }\end{array}$ & $\begin{array}{l}\text { Row crops: } 8.5-12.5 \text { oz acid equivalent (a.e.)/ } \\
\text { acre in a minimum } 10 \text {-gal volume; tree/ vine: } \\
14 \text { oz- } 1.5 \mathrm{lb} \text { a.i./acre in a minimum } 15 \text {-gal } \\
\text { volume; } 2.34 \mathrm{lb} \text { a.i./gal/season/acre. Refer to } \\
\text { label for maximum rate by crop. }\end{array}$ & $\begin{array}{l}\text { Do not chemigate. Do not irrigate until } 4 \text { hours after } \\
\text { application or cultivate from } 5 \text { days before to } 7 \text { days after } \\
\text { application. This contact herbicide requires complete } \\
\text { coverage. Avoid spraying trunks or vines directly. }\end{array}$ \\
\hline glyphosate & Refer to label for approved uses. & $\begin{array}{l}\text { POST-systemic herbicide: Apply to actively growing } \\
\text { plants 6-24 inches tall or that are at boot stage. }\end{array}$ & $\begin{array}{l}6.5 \mathrm{oz}-2.25 \mathrm{lb} \text { a.e./acre in a minimum } \\
3 \text {-gal volume; } 6 \mathrm{lb} \text { a.e. max/season/acre. }\end{array}$ & $\begin{array}{l}\text { Do not chemigate. Uniform coverage of weeds is needed } \\
\text { for control. Do not till until 3-7 days after application. }\end{array}$ \\
\hline imazethapyr & Alfalfa. & $\begin{array}{l}\text { POST: Apply when johnsongrass is } 6-12 \text { inches } \\
\text { tall. }\end{array}$ & $\begin{array}{l}0.75-1.296 \text { oz a.e./acre in a minimum } \\
\text { 10-gal volume; } 1.296 \text { oz a.e. max/acre/ } \\
\text { season. }\end{array}$ & $\begin{array}{l}\text { Do not apply to flowering crops. Do not apply within } 1 \\
\text { week of precipitation or irrigation. }\end{array}$ \\
\hline
\end{tabular}


Table 1. Herbicide general information. Read and follow approved uses, timing, and rates on the pesticide label. (continued)

\begin{tabular}{|c|c|c|c|c|}
\hline Herbicide & Approved use & Timing & Rate & Comments \\
\hline $\begin{array}{l}\text { metam } \\
\text { potassium and } \\
\text { metam sodium } \\
\text { fumigants }\end{array}$ & Refer to label for approved uses. & $\begin{array}{l}\text { Preplant-incorporated (PPI) or surface-applied: } \\
\text { See label for specific directions. }\end{array}$ & $\begin{array}{l}\text { Metam-potassium: } 174-320 \mathrm{lb} \text { a.i.; } 320 \\
\text { lb a.i. max/acre/season. Metam-sodium: } \\
160-320 \mathrm{lb} \text { a.i.i; } 320 \mathrm{lb} \text { a.i. max/acre/ } \\
\text { season. }\end{array}$ & $\begin{array}{l}\text { **POISON: PERMIT REQUIRED** Buffer zones required. Do } \\
\text { not irrigate for at least } 24 \text { hours after application. }\end{array}$ \\
\hline S-metachlor & $\begin{array}{l}\text { Beans, corn, cotton, potatoes, safflower, } \\
\text { sugarbeets, sunflowers, tomatoes. }\end{array}$ & $\begin{array}{l}\text { PRE-incorporated: Apply within } 14 \text { days of } \\
\text { planting and incorporate to } 2-3 \text { inches. PRE- } \\
\text { surface: Apply up to } 45 \text { days before planting. } \\
\text { Irrigate within } 2 \text { days of application. }\end{array}$ & $\begin{array}{l}1-2 \mathrm{lb} \text { a.i./acre in a minimum } 10-\text { gal } \\
\text { volume; } 2 \mathrm{lb} \text { a.i. max/acre/season. }\end{array}$ & Effective only on germinating seedlings. \\
\hline MSMA & Cotton. & $\begin{array}{l}\text { POST: Apply to actively growing seedlings and } \\
\text { sprouts. }\end{array}$ & $\begin{array}{l}2 \mathrm{lb} \mathrm{a.i./acre} \mathrm{in} \mathrm{a} \mathrm{minimum} 40 \text {-gal volume; } \\
2 \mathrm{lb} \mathrm{a.i.} \mathrm{max/season/acre.}\end{array}$ & $\begin{array}{l}\text { Does not require surfactant. Do not apply within } 50 \text { feet } \\
\text { of bodies of water. }\end{array}$ \\
\hline napropamide & $\begin{array}{l}\text { Almonds, artichokes, asparagus, caneberries, } \\
\text { cole crops, eggplant, grapes, kiwi, pecans, } \\
\text { peppers, strawberries, tomatoes. }\end{array}$ & $\begin{array}{l}\text { PRE-incorporated: Incorporate up to } 2 \text { inches. } \\
\text { PRE-surface: Requires immediate irrigation. }\end{array}$ & $\begin{array}{l}0.5-4 \mathrm{lb} \text { a.i./acre in a minimum } 10-\text { gal } \\
\text { volume; } 4 \mathrm{lb} \text { a.i. max/acre/season. }\end{array}$ & $\begin{array}{l}\text { Does not control emerged johnsongrass. Requires a weed- } \\
\text { free surface at application. }\end{array}$ \\
\hline nicosulfuron & Corn. & $\begin{array}{l}\text { POST: Apply to seedlings up to } 12 \text { inches tall or } \\
\text { sprouts up to } 18 \text { inches tall. }\end{array}$ & $\begin{array}{l}0.9-1.8 \text { oz a.i./acre in a minimum } 10 \text { - to } \\
15 \text {-gal volume; } 0.495 \text { oz a.i. max/acre/ } \\
\text { season. }\end{array}$ & Do not overhead-irrigate for 4 hours after application. \\
\hline norflurazon & $\begin{array}{l}\text { Alfalfa, almonds, apples, apricots, avocado, } \\
\text { caneberries, cherries, citrus, grapes, nectarines, } \\
\text { peaches, pears, pecans, plums, prunes, walnuts. }\end{array}$ & $\begin{array}{l}\text { PRE-incorporated: Apply up to } 3 \text { inches. PRE- } \\
\text { surface: Requires immediate irrigation. }\end{array}$ & $\begin{array}{l}0.5-5 \mathrm{lb} / \text { acre in a minimum } 10 \text {-gal } \\
\text { volume; } 10 \mathrm{lb} \text { max/acre/season. }\end{array}$ & $\begin{array}{l}\text { Do not chemigate except in citrus. Controls germinating } \\
\text { seedlings and suppresses rhizomes; do not spray on } \\
\text { existing crop or weed growth. }\end{array}$ \\
\hline oryzalin & $\begin{array}{l}\text { Caneberries, most tree and vine crops, noncrop } \\
\text { areas. }\end{array}$ & PRE-surface: Requires immediate irrigation. & $\begin{array}{l}2-6 \mathrm{lb} \text { a.i./acre in a minimum } 20 \text {-gal } \\
\text { volume; } 12 \mathrm{lb} \text { a.i. max/acre/season. }\end{array}$ & $\begin{array}{l}\text { Effective only on germinating seedlings. Do not apply } \\
\text { aerially. In orchards, apply only within rows. }\end{array}$ \\
\hline paraquat & Refer to label for approved uses. & $\begin{array}{l}\text { POST-contact (burndown use): Apply when } \\
\text { seedlings and sprouts are no more than } 6 \text { inches } \\
\text { tall, before crop emergence. }\end{array}$ & $\begin{array}{l}1-4 \text { pints/acre, maximum } 6 \text { pints } \\
\text { (1.5 lb a.i.). }\end{array}$ & $\begin{array}{l}\text { **POISON: PERMIT REQUIRED** Not for residential or } \\
\text { recreational use, or where children frequently visit. Do not } \\
\text { chemigate. Uniform coverage of johnsongrass is needed } \\
\text { for control. }\end{array}$ \\
\hline pendimethalin & $\begin{array}{l}\text { Alfalfa, asparagus, beans, carrots, corn, cotton, } \\
\text { eggplant, garlic, most tree and vine crops, } \\
\text { onions, peppers, potatoes, small grains, } \\
\text { strawberries, sunflowers, walnuts. }\end{array}$ & $\begin{array}{l}\text { PRE-incorporated: Apply up to } 60 \text { days before } \\
\text { planting and incorporate up to } 2 \text { inches; irrigate } \\
\text { within } 7 \text { days of treatment. PRE-surface: Apply } \\
\text { from } 45 \text { days before to } 2 \text { days after planting; } \\
\text { irrigate within } 7 \text { days of treatment. }\end{array}$ & $\begin{array}{l}12 \mathrm{oz}-2 \mathrm{lb}(2-4 \mathrm{lb} \text { in nonbearing } \\
\text { orchards) a.i./acre in a minimum } 10 \text {-gal } \\
\text { volume; } 2 \mathrm{lb} \text { a.i. max/season/acre ( } 6 \mathrm{lb} \text { in } \\
\text { nonbearing orchards). }\end{array}$ & Effective only on germinating seedlings. \\
\hline rimsulfuron & $\begin{array}{l}\text { Almonds, apples, apricots, cherries, citrus, grapes, } \\
\text { nectarines, peaches, pears, pecans, pistachios, } \\
\text { plums, potatoes, prunes, tomatoes, walnuts. }\end{array}$ & $\begin{array}{l}\text { PRE-surface: Irrigate within } 2 \text { weeks of } \\
\text { application. POST-contact: Irrigate } 1-5 \text { days } \\
\text { after application. }\end{array}$ & $\begin{array}{l}1-4 \text { oz/acre in a minimum 10-gal volume; } \\
2.5-4 \mathrm{oz} \text { max/acre/season. }\end{array}$ & $\begin{array}{l}\text { Effectively controls only young seedlings, may not } \\
\text { suppress sprouts effectively. }\end{array}$ \\
\hline sethoxydim & Refer to label for approved uses. & $\begin{array}{l}\text { POST: Apply up to } 8 \text { inches tall for seedlings } \\
\text { and sprouts, repeat application allowed after } \\
14 \text { days. }\end{array}$ & $\begin{array}{l}1.5-2.5 \text { oz/acre in a minimum } 10 \text {-gal } \\
\text { volume; } 5-10 \text { oz max/acre/season. }\end{array}$ & $\begin{array}{l}\text { Uniform coverage of johnsongrass is needed for control. } \\
\text { Do not chemigate. Do not cultivate between } 5 \text { days } \\
\text { before and } 7 \text { days after application. }\end{array}$ \\
\hline trifluralin & $\begin{array}{l}\text { Alfalfa, almonds, apricots, asparagus, beans, } \\
\text { carrots, celery, citrus, cole crops, corn (except } \\
\text { sweet), cotton, cucurbits, grapes, nectarines, } \\
\text { peaches, pecan, peppers, plums, potatoes, } \\
\text { prunes, safflower, small grains, sugarbeets, } \\
\text { sunflowers, tomatoes, walnuts. }\end{array}$ & PRE-incorporate to 3 inches. & $\begin{array}{l}0.5-2 \mathrm{lb} \text { a.i./acre in a minimum } 5 \text {-gal } \\
\text { volume; } 2 \mathrm{lb} \text { a.i. max/acre/season. }\end{array}$ & Effective only on germinating seedlings. \\
\hline
\end{tabular}




\section{References}

Calflora 2017. Taxon report 7691: Sorghum halepense. The Calflora Database, https://www.calflora.org/.

CDFA (California Department of Food and Agriculture). 2017. Encycloweedia. CDFA website, https://www.cdfa.ca.gov/.

Di Tomaso, J. M., and E. A. Healy. 2007. Weeds of California and other western states. Oakland: University of California Agriculture and Natural Resources Publication 3488.

Di Tomaso, J. M., G. B. Keyser, et al. 2013. Weed control in natural areas of the western United States. Davis: University of California Weed Research and Information Center.

Ghersa, C. M., and A. M.-G. Maria. 1991. A field method for predicting yield losses in maize caused by Johnsongrass (Sorghum halepense). Weed Technology 5(2): 279-285.

Hanson, B., et al. 2013. Selection pressure, shifting populations, and herbicide resistance and tolerance. Oakland: University of California Agriculture and Natural Resources Publication 8493. UC ANR catalog website, http://anrcatalog.ucanr.edu/ pdf/8493.pdf.

Heap, I. 2017. The international survey of herbicide-resistant weeds. WeedScience.org website, www.weedscience.org.

Howard, J. L. 2014. Sorghum halepense. U.S. Department of Agriculture Forest Service Fire Effects Information System (FEIS) website, https://www.feis-crs.org/feis/.

Jepson Flora Project. 2017. Jepson eFlora. University of California, Berkeley, Jepson Herbarium website, www.ucjeps.berkeley.edu.

Keeley, P. E., and R. J. Thullen. 1981. Control and competitiveness of Johnsongrass (Sorghum halepense) in cotton (Gossypium hirsutum). Weed Science 29(3): 356-359.

Nagabhushana, G. G., et al. 1995. Effect of nicosulfuron on Johnsongrass (Sorghum halepense) control and corn (Zea mays) performance. Weed Technology 9(3): 574-581.\{Keeley, 1981 \#781\}
Shaner, D. L., ed. 2014. Herbicide handbook. 10th ed. Lawrence, KS: Weed Science Society of America.

Smith, R., et al. 2000. Weed management for organic crops.

Oakland: University of California Division of Agriculture and Natural Resources Publication 7250. UC ANR catalog website, http://anrcatalog.ucanr.edu/pdf/7250.pdf.

University of California Statewide Integrated Pest Management Program. 2017. UC IPM Pest Management Guidelines website, www.ipm.ucdavis.edu.

To order or obtain ANR publications and other products, visit the ANR Communication Services online catalog at http://anrcatalog.ucanr.edu/ or phone 1-800-994-8849. You can also place orders by mail or FAX, or request a printed catalog of our products from

University of California

Agriculture and Natural Resources

Communication Services

1301 S. 46th Street

Building 478 - MC 3580

Richmond, CA 94804-4600

Telephone 1-800-994-8849

510-665-2195

FAX 510-665-3427

E-mail: anrcatalog@ucanr.edu

(일 The Regents of the University of California. This work is licensed under the Creative Commons Attribution-NonCommercial-NoDerivatives 4.0 International License. To view a copy of this license, visit http://creativecommons.org/licenses/by-nc-nd/4.0/ or send a letter to Creative Commons, PO Box 1866, Mountain View, CA 94042, USA.

Publication 8569

ISBN-13: 978-1-60107-978-7

The University of California, Division of Agriculture and Natural Resources (UC ANR) prohibits discrimination against or harassment of any person in any of its programs or activities on the basis of race, color, national origin, religion, sex, gender, gender expression, gender identity, pregnancy (which includes pregnancy, childbirth, and medical conditions related to pregnancy or childbirth), physical or mental disability, medical condition (cancerrelated or genetic characteristics), genetic information (including family medical history), ancestry, marital status, age, sexual orientation, citizenship, status as a protected veteran or service in the uniformed services (as defined by the Uniformed Services Employment and Reemployment Rights Act of 1994 [USERRA]), as well as state military and naval service. 
UC ANR policy prohibits retaliation against any employee or person in any of its programs or activities for bringing a complaint of discrimination or harassment. UC ANR policy also prohibits retaliation against a person who assists someone with a complaint of discrimination or harassment, or participates in any manner in an investigation or resolution of a complaint of discrimination or harassment. Retaliation includes threats, intimidation, reprisals, and/or adverse actions related to any of its programs or activities.

UC ANR is an Equal Opportunity/Affirmative Action Employer. All qualified applicants will receive consideration for employment and/or participation in any of its programs or activities without regard to race, color, religion, sex, national origin, disability, age or protected veteran status.

University policy is intended to be consistent with the provisions of applicable State and Federal laws.

Inquiries regarding the University's equal employment opportunity policies may be directed to: John Sims, Affirmative Action Contact and Title IX Officer, University of California, Agriculture and Natural Resources, 2801 Second Street, Davis, CA 95618, (530) 750-1397.

Email: jsims@ucanr.edu. Website: http://ucanr.edu/sites/anrstaff/Diversity/Affirmative

Action/.
To simplify information, trade names of products have been used. No endorsement of named or illustrated products is intended, nor is criticism implied of similar products that are not mentioned or illustrated.

An electronic copy of this publication can be found at the ANR Communication Services catalog website, http://anrcatalog.ucanr.edu/.
UC This publication has been anonymously peer reviewed for technical accuracy by University of California scientists and other qualified professionals. This review process was managed by ANR Associate Editor for Agronomy and Range Sciences Kassim Al-Khatib.

web-02/17-SB/CR 